\title{
Challenges and Instructors' Intention to Adopt and Use Open Educational Resources in Higher Education in Tanzania
}

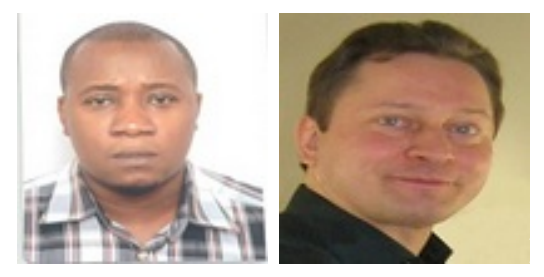

Joel Samson Mtebe and Roope Raisamo University of Tampere, Finland

\section{Abstract}

Higher education in Tanzania like in many other Sub-Saharan countries suffers from unavailability of quality teaching and learning resources due to lack of tradition, competence, and experience to develop such resources. Nevertheless, there are thousands of open educational resources (OER) freely available in the public domain that can potentially improve the quality of existing resources or help to develop new courses. The uptake and reuse of these resources in higher learning institutions (HLIs) in Tanzania has been very low. The study applied the unified theory of acceptance and use of technology (UTAUT) model to elicit instructors' intention to adopt and use OER in teaching. The paper also investigated challenges that hinder instructors to adopt and use OER. A sample of 104 instructors selected randomly from five HLIs was collected and tested against the research model using regression analysis. The study found effort expectancy had significant positive effect on instructors' intention to use OER while performance expectancy, facilitating conditions, and social influence did not have significant effect. Challenges that were found to hinder instructors to adopt and use OER are discussed. The findings of this study will help those who are involved in OER implementation to find strategies that will maximize OER adoption and usage in higher education in Tanzania.

Keywords: Open educational resources; eLearning; OER acceptance; UTAUT 


\section{Introduction}

The past decade has seen the tremendous development of information and communication technologies (ICT) and the internet in Tanzania. The recent rollout of SEACOM marine cable has increased internet speed up to $155 \mathrm{Mbps}$ as well as reducing telecommunication costs by 95\% (Swarts \& Wachira, 2010). Recently, the government has also exempted all ICT equipment imported in the country from value added tax (Sife, Lwoga, \& Sanga, 2007). Consequently, the price of ICT equipment has decreased significantly and it has become affordable to the majority of Tanzanians. These developments have heightened the need for higher learning institutions (HLIs) to use ICT to embrace educational delivery.

Naturally, institutions have been spending a considerable amount of resources to procure, install, and maintain various ICT equipment as well as information systems to complement face-to-face delivery. For example, $80.2 \%$ of HLIs in Tanzania had installed eLearning systems by the end of 2011 (78\% Moodle and 2.5\% Blackboard) (Munguatosha, Muyinda, \& Lubega, 2011) while others were using audiotapes, CDROMs, videotapes, video conferencing, and other eLearning technologies (Lwoga, 2012).

Despite massive investments made by institutions to procure and manage various educational technologies, far too little attention has been paid to develop course content for students. The majority of existing content is text based in the form of course handouts with minimum content, without multimedia to make them more interactive (Lwoga, 2012). As a result, many institutions have continued to rely on printed resources which are expensive and difficult to share with a wider group of learners (Lwoga, 2012; Nyandara, 2012).

As the cost of text books and other educational resources from commercial companies continue to rise, institutions normally tend to use out-dated books, old course content, or poorly designed learning resources (Keats, 2003; Ngugi, 2011). Clearly, the use of such resources has implication on the quality of graduates. In fact, a majority of instructors in developing countries do not have expertise and experience to develop quality educational resources (Unwin et al., 2010). Nonetheless, the recent emergence of open educational resources (OER) is described as one of the main solutions to help institutions to acquire quality learning resources at no cost.

OER are freely and openly available digitized learning resources that can be adapted, modified, and re-used for teaching, learning, and research (OECD, 2007). The idea behind OER was first introduced by United Nations Educational, Scientific and Cultural Organization (UNESCO) in a Forum on the Impact of Open Courseware for Higher Education in Developing Countries 2002 hosted by UNESCO in Paris, France (UNESCO, 2002). The forum cemented the need to release these resources in order to expand access to education specifically in developing countries. As a result, thousands 
of OER spanning across all disciplines have been made available in the public domain through the support of Organization for Economic Co-operation and Development (OECD), the William and Flora Hewlett Foundation, the Commonwealth of Learning (COL), and UNESCO. They include full courses, course modules, video of lectures, homework assignments, simulations, and electronic textbooks.

By the end of 2007, over 3,000 courses from over 300 universities were available (OECD, 2007). These included 1,900 courses from Massachusetts Institute of Technology (MIT), 2,500 courses from over 200 universities under OCW Consortium, and more than 1,500 courses under J apanese OCW Consortium (Butcher, n.d.). Others include 750 resources from China Open Resources for Education (CORE) and more than 22,500 resources from Multimedia Educational Resource for Learning and Teaching Online (MERLOT) (Yuan, Mac, \& Kraan, 2008). Moreover, there are already African-based initiatives that have shared thousands of locally developed OER. Some notable initiatives are OER Africa, Teacher Education in Sub-Saharan Africa (TESSA), and UCT Open Content.

Despite free availability of these resources, their uptake and reuse in many Sub-Saharan countries like Tanzania is very low (Freitas, 2012; Hoosen, 2012; Unwin et al., 2010). MIT OCW statistics show that only 2\% of MIT OCW traffic since 2004 has come from users in Sub-Saharan Africa (MIT, 2013). In Tanzania, for example, despite efforts made by Open University of Tanzania (OUT) to adapt and use MIT OCW, only $21.8 \%$ of 150 respondents indicated awareness of their existence (Samzugi \& Mwinyimbegu, 2013). Similarly, since University of Dar es Salaam signed an agreement with MIT a few years ago to use MIT OCW, none of the departments has reported using these resources.

So far, however, there has been little research around the use of OER in the African context (Percy \& Belle, 2012). A majority of existing OER studies focus on development and publication of OER repositories as well as on the integration of policies in various institutions (Andrad et al., 2011). Therefore, this study focused on investigating reasons behind low uptake and reuse of OER in higher education in Tanzania. Specifically, the study aimed to

- elicit instructors' behavioral intention to adopt and use OER in teaching, and

- identify challenges that hinder instructors to adopt and use OER in teaching.

The study was conducted in five HLIs located in Tanzania. These institutions are:

- University of Dar Es Salaam (UDSM),

- Ardhi University (ARU),

- Dar Es Salaam University College of Education (DUCE),

- Dar Es Salaam Institute of Technology (DIT), and

- Mkwawa University College of Education (MUCE). 


\section{The Importance of OER for Higher Education in Tanzania}

The availability of OER in the public domain can offer several benefits to higher education in Tanzania. These include helping instructors to improve the quality of existing courses or develop new courses through adapting, modifying, and reusing thousands of freely available courses in the public domain. OER can also improve the quality of locally developed content by sharing course content under open licenses through receiving plenty of peer reviews from other academics in OER communities. Additionally, through participating in OER communities staff can acquire skills and competences to develop quality course content (Wilson-Strydom, 2009). These skills include content/subject matter, instructional techniques, online approaches, review processes, production, presentation, and publishing of educational materials.

Moreover, OER can reduce social inequalities by complementing existing blended learning courses offered by several institutions in Tanzania. In this case, OER can widen access of education to disadvantaged learners such as those who are located in remote areas or unable to study due to work or family commitments (Butcher, 2011; Freitas, 2012). In practical terms, since $90 \%$ of institutions in Tanzania are government funded, sharing and reuse of content amongst institutions will make efficient utilization of taxpayers' money, thus everyone benefits (Hylén, 2006; Sclater, 2009).

Another advantage of OER in higher education is to attract more students, increase institutional reputation, and attract research funding and new partnerships (Butcher, 2011; Hylén, 2006; Sclater, 2009; UNESCO \& COL, 2011). This was demonstrated by MIT, which found that students' awareness of their freely available courses influenced $35 \%$ of new students to apply to various courses (MIT, 2006). Similarly, at least 4,400 new students who registered on courses offered by Open University of UK had accessed the same courses on the OpenLearn site before as OER (McAndrew et al., 2008). Moreover, MIT and OpenLearn's public image and reputation have increased tremendously since they started OER projects and have attracted dozens of funding agreements and partnerships. The same benefits can be reaped by HLIs in Tanzania by participating in OER initiatives.

\section{Theoretical Framework}

The study adopted the unified theory of acceptance and use of technology (UTAUT) model to examine instructors' behavioral intention to adopt and use OER in teaching. The model was developed by Venkatesh et al. (2003) by combining eight similar technology acceptance models. The models that were combined to form UTAUT are: technology acceptance model (TAM), innovation diffusion theory (IDT), theory of reasoned action (TRA), and motivation model (MM). Other models include theory of planned behavior (TPB), combined TAM and TPB, model of PC utilization (MPCU), and social cognitive theory (SCT). 
The model consists of four key constructs: performance expectancy, effort expectancy, social influence, and facilitating conditions (see Figure 1). These four constructs are direct determinants of usage intention and behavior. Moreover, the variables gender, age, experience, and voluntariness of use moderate the key relationships in the model. This model has demonstrated the robustness and validity in predicting the acceptance of various new IT innovations which influenced the choice of the model for this study. Moreover, it was able to explain 70\%of the variance in behavioral intention in IT and about $50 \%$ in actual use, which was better than the other eight models (Venkatesh et al., 2003).

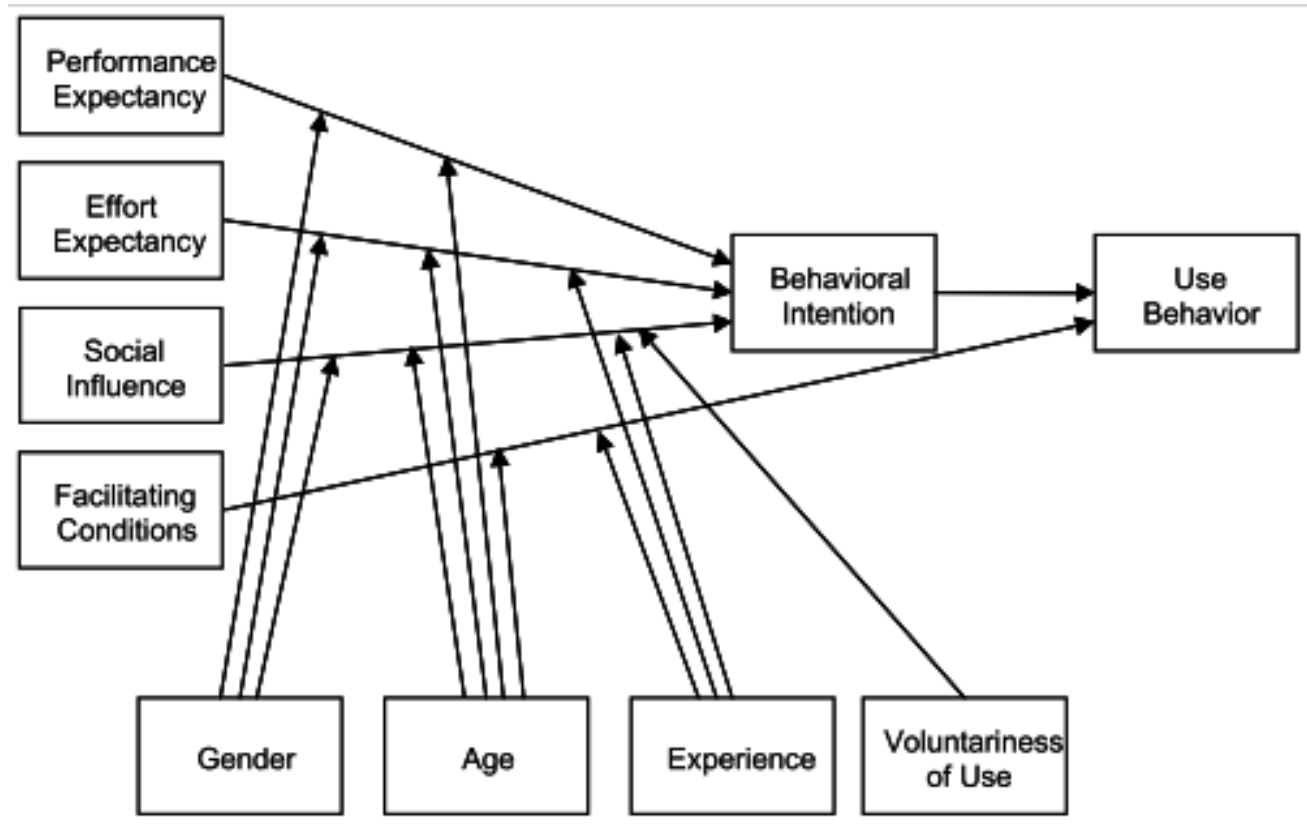

Figure 1. The UTAUT model (Source: Venkatesh et al., 2003, p. 447).

\section{Research Model and Hypotheses}

A majority of studies that adopted UTAUT have extended the model by including new variables or reducing existing variables to suit a particular context of the study. Likewise, this study extended the model to suit the context of OER adoption in Tanzania. OER is expected to increase accessibility of educational resources that will be integrated into existing courses or used to develop new courses. In this case voluntariness of use in UTAUT was removed. Also, this study does not investigate the effect of gender, age, or experience of instructors in behavioral intention to use OER. Therefore gender, experience, and age were also removed. The hypotheses and constructs are below. 


\section{Performance expectancy.}

This is the degree to which instructors believe that using OER will help them to enhance their teaching performance (Venkatesh et al., 2003). Venkatesh et al. also demonstrated that performance expectancy is the strongest predictor of behavioural intention to use several technologies in both voluntary and involuntary settings. In a similar study conducted in Africa with 96 respondents, performance expectancy was found to have strong influence for instructors to adopt and use OER in teaching (Percy \& Belle, 2012). Adapting performance expectancy to the OER context, instructors are expected to find OER useful and will enable them to accomplish teaching activities more quickly and flexibly or even help them to increase their teaching effectiveness. Therefore, the hypothesis can be explained as follows:

Hypothesis 1: Performance expectancy has a positive effect on behavioural intention to adopt and use OER.

\section{Effort expectancy.}

This represents a degree of easiness associated with locating, adapting, and using OER (Venkatesh et al., 2003). Therefore, the study hypothesizes that the acceptance to adopt and use OER will depend on whether instructors believe using OER will be easy and free of effort. Several studies have found effort expectancy to be an important predictor of information technology usage. Likewise, Percy and Belle (2012) found effort expectancy to have a positive influence on adopting and using OER in Africa. Therefore, the proposition is derived as follows:

Hypothesis 2: Effort expectancy has a positive effect on behavioural intention to adopt and use OER.

\section{Social influence.}

This represents a degree to which instructors perceive how important it is for others to believe they should adopt and use OER (Venkatesh et al., 2003). This construct was considered a very important aspect in predicting acceptance of IT in previous studies such as TRA and TAM 2. These studies called it subjective norms. Therefore, it is expected the OER adoption rate will increase if instructors perceive their colleagues in the department or institution management believe they should use it. The hypothesis can be explained as follows:

Hypothesis 3: Social influence has a positive effect on behavioural intention to adopt and use OER.

\section{Facilitating conditions.}

Venkatesh et al. (2003) define facilitating conditions as "the degree to which an individual believes that an organizational and technical infrastructure exists to support the use of the system" (p. 453). Therefore, the OER adoption rate will increase if 
instructors believe that institutions have systems and services to support the application and use of OER in teaching. In the context of OER, these support systems can be the availability of reliable internet and having the necessary skills to be able to use OER. Therefore, the proposition is derived as follows:

Hypothesis 4: Facilitating conditions has a positive effect on behavioural intention to adopt and use OER.

The research model is shown in Figure 2.

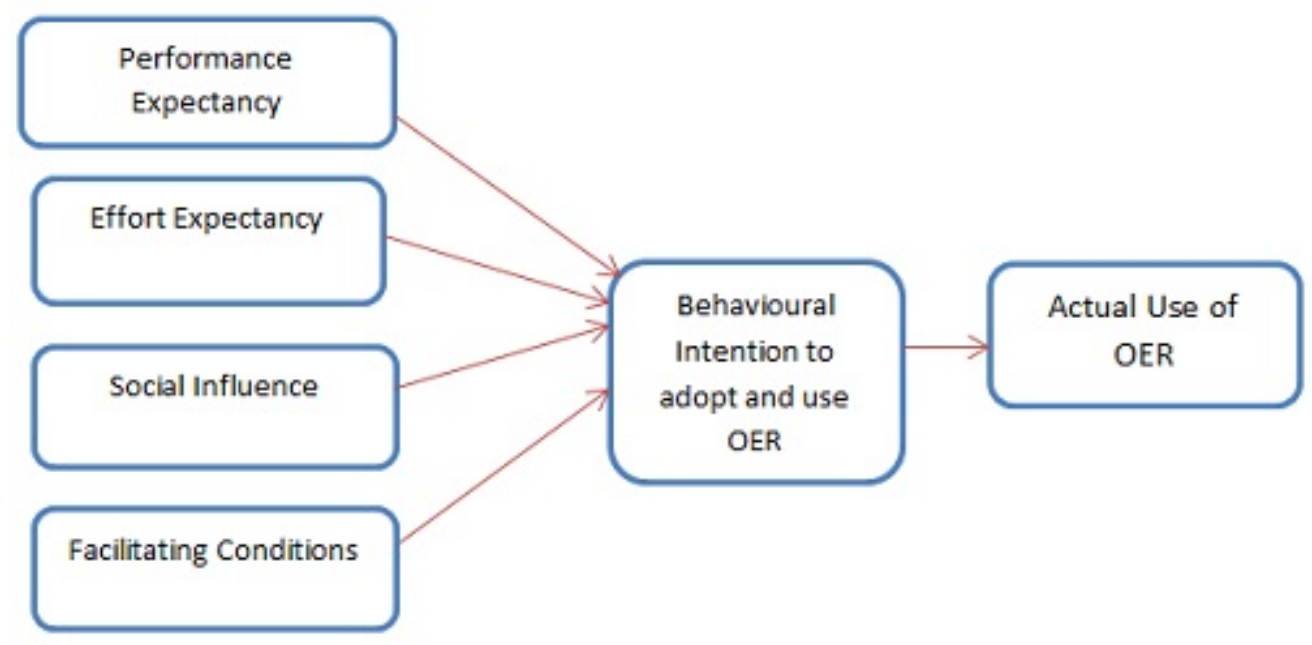

Figure 2. Research model.

\section{Research Methodology}

The study adopted a research instrument developed by Venkatesh et al. (2003) which uses a five-point Likert scale ranging from 1 (strongly disagree) to 5 (strongly agree). The questionnaire was modified by re-wording items to suit the context of the study (see Appendix). New items were added to assess how instructors use internet services to prepare and share learning resources. The questionnaire was created using Google Docs, and emailed to 608 instructors selected randomly from five institutions. Ninetysix emails were undelivered. Therefore, a total of 512 responses could have been received. However, a sample of 104 instructors out of 512 usable responses was obtained. This is $20.3 \%$ of all respondents.

All respondents were guaranteed confidentiality of their individual responses, and the name field was treated as optional. Data was collected through Google Docs, and, thereafter, recorded directly into an Excel file. The data collection was undertaken between April and J une 2013. The study used Statistical Packages for Social Science (SPSS) version 20 to analyze data. 


\section{Research Results}

\section{Demographic information.}

The study revealed that $75 \%$ of respondents were males, and $15 \%$ were females. In terms of institution distribution, $52.9 \%$ of respondents were from UDSM, $12.5 \%$ from DUCE, 8.7\% from DIT, 18.7\% from MUCE, and 7.7\% from ARU. Moreover, $82 \%$ indicated they shared their course notes with other instructors, while $18 \%$ did not. When they were asked if they could share their lecture notes with other people via internet for free, 84.6\% said yes, while 15.4 said no. However, 83\% said they have heard about OER before, while $17 \%$ said they have never heard about it. Table 1 shows the demographic information of the respondents.

Table 1

Respondents' Demographic Profile

\begin{tabular}{|c|c|c|c|}
\hline Respondents profile & Classification & Frequency & Percentage \\
\hline \multirow{2}{*}{ Gender } & Male & 78 & 75 \\
\hline & Female & 26 & 25 \\
\hline \multirow{5}{*}{ Institution } & UDSM & 55 & 52.9 \\
\hline & DUCE & 13 & 12.5 \\
\hline & DIT & 9 & 8.7 \\
\hline & MUCE & 19 & 18.3 \\
\hline & ARU & 8 & 7.7 \\
\hline \multirow{2}{*}{$\begin{array}{l}\text { Can you share your course } \\
\text { notes via internet for } \\
\text { people to access freely? }\end{array}$} & Yes & 88 & 84.6 \\
\hline & No & 16 & 15.4 \\
\hline \multirow{2}{*}{$\begin{array}{l}\text { Have you ever shared } \\
\text { your course notes with } \\
\text { other lecturers? }\end{array}$} & Yes & 85 & 82 \\
\hline & No & 19 & 18 \\
\hline \multirow{2}{*}{$\begin{array}{l}\text { Have you ever heard } \\
\text { about OER before? }\end{array}$} & Yes & 86 & 83 \\
\hline & No & 18 & 17 \\
\hline
\end{tabular}

\section{Instructors' Acceptance to Adopt and Use OER}

To explore instructors' intention to adopt and use OER, data were tested against the research model using linear regression analysis. First, the reliability of the research instrument as well as individual constructs was measured.

\section{Research reliability and validity.}

To measure reliability of the instrument and constructs, Cronbach's alpha ( $\alpha$ ) was used. 
Based on SPSS results, the Cronbach's alpha coefficient for the 19-item instrument was 0.877 exceeding 0.70 required for basic research. Therefore, the data collection tool was reliable. As shown in Table 2, Cronbach's alpha values of the five constructs ranged from 0.670 to 0.927 which are all above 0.5 .

Table 2

Cronbach's Alpha Coefficients for Construct Reliability Measurement

\begin{tabular}{|l|l|l|}
\hline No. & Construct & Cronbach alpha $(\alpha)$ \\
\hline 1. & Performance expectancy & 0.846 \\
\hline 2. & Effort expectancy & 0.906 \\
\hline 3. & Social influence & 0.750 \\
\hline 4. & Facilitating conditions & 0.670 \\
\hline 5. & Behavioural intention & 0.927 \\
\hline
\end{tabular}

The overall questionnaire was considered valid as it used the same items from previous surveys without adding new or deleting existing items.

\section{Assessment of research model.}

To assess the research model, a confirmatory factors analysis was conducted. Five factors loaded successfully in pattern matrix table using direct oblimin rotation method. The five factors were then subjected to linear regression analysis in order to measure the success of the model and predict causal relationship between independent variables (IVs) (performance expectancy, facilitating conditions, effort expectancy, and social influence), and the dependent variable (DV) (behavioral intention to use OER).

Using enter method, a significant model emerged: $F(4,99)=4.563654, \mathrm{p}<.005$. The model explains $12.2 \%$ of the variance (Adjusted $R$ Square $=0.122$ ) on instructors' behavioral intention to adopt and use OER in HLIs in Tanzania. Clearly, there are factors other than the four proposed in this model which can be used to predict instructors' behavioral intention to adopt and use OER. However, this is still a good model as Gaur and Gaur (2009, p. 109) pointed out that as much as lower value $\mathrm{R}$ square $0.10-0.20$ is acceptable in social science research. Table 3 shows a summary of the research model. 
Table 3

Model Summary

\begin{tabular}{|l|l|l|l|l|}
\hline Model & $\mathrm{R}$ & R square & $\begin{array}{l}\text { Adjusted R } \\
\text { square }\end{array}$ & $\begin{array}{l}\text { Std. error of } \\
\text { the estimate }\end{array}$ \\
\hline 1 & $.395^{\mathrm{a}}$ & .156 & .122 & .937246 \\
\hline
\end{tabular}

\section{Hypothesis testing.}

To test the proposed research hypotheses, regression analysis was used to determine the causal relationship between the DV and four IVs. Table 4 shows the result of nonstandardized and standardized regression coefficients for the constructs entered in the model. Similarly, Table 5 shows a summary of predictive factors in terms of beta values for each hypothesis obtained from regression analysis. The results show that three hypotheses did not have significant effect on instructors' intention to adopt and use OER; values were not less than 0.05. However, effort expectancy (beta $=0.25$ ) had significant positive effect on instructors' behavioral intention to adopt and use OER in teaching.

Table 4

Unstandardized and Standardized Regression Coefficients for the Constructs Entered in the Model

\begin{tabular}{|l|r|r|r|r|r|}
\hline \multirow{2}{*}{ Constructs } & \multicolumn{2}{|c|}{$\begin{array}{c}\text { Unstandardized } \\
\text { coefficients }\end{array}$} & $\begin{array}{c}\text { Standardized } \\
\text { coefficients }\end{array}$ & \multirow{2}{*}{ Sig. } & \\
\cline { 2 - 5 } & \multicolumn{1}{c|}{ B } & Std. Error & Beta & & \\
\hline (Constant) & $\begin{array}{r}3.603 \mathrm{E}- \\
017\end{array}$ & .092 & & .000 & 1.000 \\
\hline $\begin{array}{l}\text { Performance } \\
\text { Expectancy }\end{array}$ & -.187 & .102 & -.187 & -1.839 & .069 \\
\hline Facilitating conditions & -.170 & .097 & -.170 & -1.752 & .083 \\
\hline Effort expectancy & .250 & .104 & $.250^{*}$ & 2.400 & .018 \\
\hline Social influence & -.094 & .103 & -.094 & -.908 & .366 \\
\hline
\end{tabular}

$* \mathrm{p}<0.05$

A summary of how the hypotheses have been tested is shown in Table 5. 
Table 5

Summary of Results Hypothesis Testing

\begin{tabular}{|l|l|l|}
\hline Hypothesis & Results & Conclusion \\
\hline $\begin{array}{l}\text { Hypothesis 1: Performance expectancy } \\
\text { has a positive effect on behavioural } \\
\text { intention to adopt and use OER. }\end{array}$ & $\begin{array}{l}\text { Not significant (Beta }=- \\
0.187, \mathrm{p}<0.069)\end{array}$ & Not supported \\
\hline $\begin{array}{l}\text { Hypothesis 2: Effort expectancy has a } \\
\text { positive effect on behavioural } \\
\text { intention to adopt and use OER. }\end{array}$ & $\begin{array}{l}\text { Yes significant (Beta }= \\
0.250, \mathrm{p}<0.005)\end{array}$ & Supported \\
\hline $\begin{array}{l}\text { Hypothesis 3: Social influence has a } \\
\text { positive effect on behavioural } \\
\text { intention to adopt and use OER. }\end{array}$ & $\begin{array}{l}\text { Not significant (Beta }=- \\
0.094, \mathrm{p}<0.366)\end{array}$ & Not supported \\
\hline $\begin{array}{l}\text { Hypothesis 4: Facilitating conditions } \\
\text { has a positive effect on behavioural } \\
\text { intention to adopt and use OER. }\end{array}$ & $\begin{array}{l}\text { Not significant (Beta }=- \\
0.170, \mathrm{p}<0.083)\end{array}$ & Not supported \\
& & \\
\hline
\end{tabular}

\section{Challenges Facing Instructors to Adopt OER in Higher Education}

Finally, instructors were asked to provide their opinion as to why instructors in HLIs in Tanzania do not use OER in teaching. The following are some of the challenges mentioned by instructors.

\section{Technology.}

Some HLIs in Tanzania are still faced with inadequate ICT infrastructure which hinders the adoption and use of OER in teaching. In some institutions access to computers is still limited while some are faced with unreliable internet services and low bandwidth. Below are some of the comments from instructors:

...lack of facilities and equipment like computers, intranet and reliable internet connections....

...lack of facilities, reliable power and slow internet connection and unreliable

...Readiness and willingness are problems. But the availability of ICT facilities is a limiting factor. 


\section{Awareness of intellectual property and copyright issues.}

The study revealed that some instructors do not have knowledge about copyright and intellectual property issues. In this regard, instructors do not know which resources should be shared in the public domain, and which rights should be reserved to the institution or to the authors. For example, one instructor said “.. I don't have knowledge on the existence of OER and how to use OER but also fear to share my materials with fear of copyright issues..."

\section{Relevance and quality of OER.}

This study found a majority of instructors could not find resources which are relevant to their contexts. Moreover, some of the instructors are suspicious about the quality of OER and other resources from the internet. Here are some of the comments from instructors:

...Many of the OER are not exhaustive enough. Many are shallow, not complete. In order to use them, you need to take them as a starting point but you may need to edit to a big percentage to suit your context as per the syllabus.

... the irrelevance of most of the material available on OER to our course content/ outline."

... I don't trust the authenticity of internet based materials.

...in my institution in particular, the available OER does not fit much to the curriculums (which are competence based), although they are helpful in instructional composition.

\section{Awareness about the existence of OER.}

Another important finding was that some instructors are still unaware of the existence of OER. This was evident from the comments below:

...we are un-aware of OERs and even if some have glimpse of it lack knowledge on how to access them...

...Most of them they are not informed, resourceful persons are few to help them adapt, there is no infrastructure set for them to adapt for OER in their colleges, most of lecturers are newbies to web 2.0 technology 
... I think lack of information about the OER its advantages and usefulness

...May be because, they lack some Technics on how they can have access to web resources

...Most of them are not exposed/aware of the animal called OER

...Most of them they do not know how to use OER. Lack of knowledge

Moreover, some who are aware of OER pointed out that they do not have the skills and knowledge to access and use them.

\section{Discussion}

This study set out to explore challenges and instructors' behavioral intentions to adopt and use OER in teaching. One of the most interesting findings was that many instructors are aware of the existence of OER ( $83 \%$ of instructors) and they were willing to share their course notes freely via the internet (84.6\% of instructors). The study also found that the proposed model explains $12.2 \%$ of the variance (Adjusted R Square $=$ 0.122 ) to adopt and use OER in HLIs. Moreover, the study did not find any significant effect on instructors' intention to adopt and use OER using three factors namely facilitating conditions, performance expectancy, and social influence. In general, therefore, it seems that there are factors other than these four which can be used to predict instructors acceptance' to adopt and use OER.

On the other hand, we found effort expectancy to have significant positive effect on instructors' intention to adopt and use OER. These results suggest that instructors believe OER will be easy to use and free of efforts. The findings are consistent with similar studies, Percy and Belle (2012) and Dulle and Minishi-Majanja (2011), which assessed the acceptance of OER in Africa and open access in public universities in Tanzania respectively. These findings have important implications for OER and OER repository developers. They should improve the user-friendliness and ease of use of OER and OER repositories in order to attract more instructors to adopt and use them.

Some instructors described inadequate ICT infrastructure as one of the challenges they are faced with when adopting and using OER in teaching. These findings are consistent with a similar study conducted at the Open University of Tanzania (Samzugi \& Mwinyimbegu, 2013). This study found a low level of internet connectivity and an inadequate number of computers were hindrance factors to adopt and use OER. According to Bateman (2008), despite commonalities that exist amongst African 
countries, there also exists considerable diversity in terms of infrastructural and contextual challenges. In some countries, ICT infrastructure is improving very fast compared to others. For example, Ngimwaa and Wilsona (2012) found low technology levels was not a hindrance factor to adopt OER in a study conducted in Kenya, Uganda, and South Africa using a survey of 19 participants from TESSA.

Similarly, the Government of Tanzania has been improving ICT infrastructure by rolling out SEACOM marine fibre cable and has exempted all ICT facilities from import taxes (Lwoga, 2012). The SEACOM marine cable has reduced telecommunication costs by $95 \%$ (Swarts \& Wachira, 2010) as well as increasing bandwidth up to $155 \mathrm{MBps}$ (Lwoga, 2012). Some institutions are already connected and many will be connected in the near future (Mtebe \& Twaakyondo, 2012).

Moreover, we found that some instructors do not use OER due to unawareness of copyright issues related to OER implementation. Unexpectedly, $84.6 \%$ of instructors were willing to share their course notes freely via the internet. Therefore, there is an urgent need for institutions to create awareness of copyright issues in order to enable instructors to adopt OER and share their resources via the internet. It seems that this is a big problem as several studies (Hoosen, 2012; Percy \& Belle, 2012) that were conducted in Africa had similar findings. Institutions should be advised to make use of Creative Commons licensing which has already addressed various license options that can be attached to OER (Sclater, 2009).

The study also revealed that some instructors could not find OER relevant to their curricula or their context. This could be attributed to the fact that many instructors are not aware of the OER repositories with resources relevant to their courses. In addition, some instructors were suspicious about the quality of OER and materials from the internet in general. However, instructors should be advised to use existing quality assurance procedures set within their institutions to choose OER for their courses (UNESCO \& COL, 2011).

In fact, the responsibility of ensuring the quality of OER chosen, and how they are integrated into teaching activities for a particular course, resides in instructors themselves (Butcher, 2011; Dinevski, 2008). Once this is explained clearly to instructors, definitely they will start adopting and using them. At institutional level, a majority of institutions in Tanzania do not have institutional policies that encourage instructors to create and share educational resources. Existing policies were developed when OER was at an early stage of implementation. For example, UDSM ICT policy was developed in 2006, while that of OUT was developed in 2009. Unless institutions review their existing policies, it will be very difficult for institutions in Tanzania to benefit from OER initiatives as any effort to do so will encounter several challenges that can be resolved by policies. According to Butcher (2011), at least four main policies need to be reviewed for smooth implementation of OER in a given institution. These policies are: 
intellectual property rights and copyright policy, human resource policy guidelines, ICT policy, and materials development and quality assurance policy.

However, many institutions in Tanzania do not have expertise to develop OER enabled policies. These institutions can still benefit from organizations such as SAIDE, OER Africa, and UNESCO which have been supporting HLIs in Africa to review and develop policies that enable friendly adoption and usage of OER. For example, OER Africa has recently supported University of Ghana and the Kwame Nkrumah University of Science and Technology to review their policies (Ngugi, 2011). As a result, the efforts spent to develop course content have been valued the same way as effort spent to conduct research and are part of promotion considerations.

\section{Recommendations for Future Research}

The proposed model for this study accounts for $12.2 \%$ variance in the behavioural intention to adopt and use OER in teaching. Although this is an acceptable percentage in social science research, it is clear that there are other factors that can be used to predict behavioural intention to adopt and use OER. Considerably more work will need to be done by adding new factors to the UTAUT model in order to predict behavioural intention to use OER in teaching. Some of the factors that can be considered are attitude, information quality, and awareness, which were used by Percy and Belle (2012) and Dulle and Minishi-Majanja (2011) in similar studies.

Furthermore, individual perceptions change over time as users gain experience (Venkatesh et al., 2003). Therefore, the results of this study should be considered as perceptions and intention to adopt and use OER at a single point in time. Future research should validate this model in order to apply the findings at a given time. Despite these limitations, this study provides insights on factors that contribute to successful adoption of OER in higher education in Tanzania.

\section{Conclusion}

The advantages of OER to enhance education in Sub-Saharan countries like Tanzania are well documented. However, the perceived benefits cannot be realised if instructors do not use these resources to embrace their courses. There is a need to find reasons behind low uptake of these resources in higher education in order to identify corrective measures that will help institutions to maximise usage of these resources in Tanzania. Accordingly, this paper was set to explore challenges facing instructors to adopt and use OER as well as elicit their behavioural intention to use and adopt OER.

We found that performance expectancy, facilitating conditions, and social influence did not have a statistically significant effect on instructors' behavioural intention to adopt and use OER. However, instructors believe that OER will be easy to use with effort 
expectancy having positive effect on intention to adopt and use OER. We also found that unreliable internet connection, quality of OER, and lack of awareness of copyright issues related to OER are the main challenges hindering instructors to adopt and use OER. The findings of this study can help institutions in Tanzania to find strategies that will maximize adoption and usage of OER in teaching.

\section{Acknowledgement}

The authors appreciatively acknowledge the financial support provided by a grant from University of Dar Es Salaam, World Bank project and the support from University of Tampere for preparing this article. Moreover, the authors would like to thank instructors from five institutions, ARU, UDSM, DUCE, DIT, and MUCE, who willingly participated in the study. 


\section{References}

Andrad, A., Ehlers, U.-D., Caine, A., Carneiro, R., Conole, G., Kairamo, A.-K., ... Holmberg, C. (2011). Beyond OER: Shifting focus to open educational practices. Retrieved from http:// www.oerasia.org/ OERResources/ 8.pdf

Bateman, P. (2008). Revisiting the challenges for higher education in Sub-Saharan Africa : The role of the open educational resources movement OER Africa (pp. 1-66). Nairobi, Kenya.

Butcher, N. (n.d.). OER dossier : Open educational resources and higher education. South Africa. Retrieved from http:// www.col.org/SiteCollectionDocuments/OER_Open_Educational_Resou rces_and_Higher_Education.pdf

Butcher, N. (2011). A basic guide to open educational resources (OER) (pp. 1- 134). Vancouver \& Paris: COL. Retrieved from http:// www.col.org/resources/publications/Pages/detail.aspx?PID=357

Dinevski, D. (2008). Open educational resources and lifelong learning. In ITI 2008 30th International Conference on Information Technology Interfaces (pp. 117122). Ieee. doi:10.1109/ ITI.2008.4588393

Dulle, F. W., \&Minishi-Majanja, M. K. (2011). The suitability of the unified theory of acceptance and use of technology (UTAUT) model in open access adoption studies. Information Development, 27(1), 32-45.

doi: $10.1177 / 0266666910385375$

Freitas, D. (2012). Fostering social inclusion through open educational resources (OER). Distance Education, 33(2), 131- 134.

Gaur, A. S., \& Gaur, S. S. (2009). Statistical methods for practice and research: A guide to data analysis using SPSS (2nd ed., p. 208). SAGE Publications India Pvt Ltd. doi:10.4135/9788132108306

Hoosen, S. (2012). Survey on governments' open educational resources (OER) policies (pp. 1-40). Retrieved from http:// www.col.org/ resources/publications/Pages/detail.aspx?PID=408

Hylén, J . (2006). Open educational resources : Opportunities and challenges. In Open Education. Retrieved from http://library.oum.edu.my/oumlib/sites/default/files/file_attachments/odlresources/386010/oer-opportunities.pdf 
Keats, D. (2003). Collaborative development of open content: A process model to unlock the potential for African universities. First Monday, 8(2). Retrieved from

http:/ firstmonday.org/ htbin/ cgiwrap/ bin/ ojs/ index.php/ fm/rt/ printerFriendl y/ 1031/952

Lwoga, E. (2012). Making learning and Web 2.0 technologies work for higher learning institutions in Africa. Campus-Wide Information Systems, 29(2), 90- 107. doi:10.1108/ 10650741211212359

McAndrew, P., Inamorato, A., Lane, A., Godwin, S., Okada, A., Wilson, T., ...Webb, R. (2008). OpenLearn: Research report 2006- 2008. Retrieved from http://www3.open.ac.uk/ events/6/2009727_62936_o1.pdf

MIT. (2006). 2005 program evaluation findings report (pp. 1- 138).

MIT. (2013). Site statistics. Retrieved April 08, 2013, from http:// ocw.mit.edu/about/ site-statistics/

Mtebe, J . S., \& Twaakyondo, H. M. (2012). Developing and using animations and simulations to teach computer science courses: The case of University of Dar Es Salaam. In 2012 International Conference on E-Learning and E-Technologies in Education (ICEEE) (pp. 240- 246). Lodz, Poland: IEEE. doi:10.1109/ICeLeTE.2012.6333383

Munguatosha, G. M., Muyinda, P. B., \&Lubega, J . T. (2011). A social networked learning adoption model for higher education institutions in developing countries. On the Horizon, 19(4), 307- 320. doi:10.1108/ 10748121111179439

Ngimwaa, P., \&Wilsona, T. (2012). An empirical investigation of the emergent issues around OER adoption in Sub-Saharan Africa. Learning, Media and Technology, 37(4), 398-413. doi:10.1080/17439884.2012.685076

Ngugi, C. N. (2011). OER in Africa's higher education institutions. Distance Education, 32(2), 277- 287. doi:10.1080/01587919.2011.584853

Nyandara, Z. I. (2012). Challenges and opportunities of technology based instruction in open and distance learning: A comparative study of Tanzania and China. In 5th UbuntuNet Alliance annual conference (pp. 130-145). Retrieved from http:// www.ubuntunet.net/sites/ubuntunet.net/ files/ nyandaraz.pdf

OECD. (2007). Giving knowledge for free: The emergence of open educational resources. Retrieved from http:// www.oecd.org/ dataoecd/35/ 7/38654317.pdf

Percy, T., \& Belle, J . Van. (2012). Exploring the barriers and enablers to the use of open educational resources by university academics in Africa. Open source systems: 
Long-term sustainability (pp. 112- 128). Retrieved from http://link.springer.com/ chapter/ 10.1007/978-3-642-33442-9 8

Samzugi, A. S., \& Mwinyimbegu, C. M. (2013). Accessibility of open educational resources for distance education learners: The case of The Open University of Tanzania. Huria J ournal of OUT, 14(76-88).

Sclater, N. (2009). The organisational impact of open educational resources. In U. D. Ehlers \& D. Schneckenberg (Eds.), Changing cultures in higher education: Moving ahead to future learning. Berlin / London. Retrieved from http:// oro.open.ac.uk/ 18765/2/ BC228F30.pdf

Sife, A. S., Lwoga, E. T., \& Sanga, C. (2007). New technologies for teaching and learning: Challenges for higher learning institutions in developing countries. International J ournal of Education and Development using Information and Communication Technology (IJ EDICT), 3(2), 57-67.

Swarts, P., \&Wachira, E. (2010). Tanzania: ICT in education situational analysis. global e-schools and communities initiative. Retrieved from http://www.gesci.org/assets/files/Knowledge Centre/ Situational Analysis Tanzania.pdf

UNESCO. (2002). UNESCO promotes new initiative for free educational resources on the Internet. Retrieved from http://www.unesco.org/education/news_en/080702_free_edu_ress.shtml

UNESCO, \& COL. (2011). Guidelines for open educational resources (OER) in higher education. Paris \&Vancouver: Author.

Unwin, T., Kleessen, B., Hollow, D., Williams, J ., Oloo, L. M., Alwala, J ., ... Muianga, X. (2010). Digital learning management systems in Africa: Myths and realities. Open Learning: The J ournal of Open and Distance Learning, 25(1), 5- 23. doi:10.1080/02680510903482033

Venkatesh, V., Morris, M. G., Hall, M., Davis, G. B., Davis, F. D., \&Walton, S. M. (2003). User acceptance of information technology : Toward a unified view 1. MIS Quarterly, 27(3), 425- 478.

Wilson-Strydom, M. (2009). The potential of open educational resources OER Africa. Retrieved from http:// www.oerafrica.org/ understandingoer/UnderstandingOER/ ResourceDet ails/tabid/ 1424/ mctl/Details/id/ 36389/Default.aspx 
Yuan, L., Mac, S., \& Kraan, W. (2008). Open educational resources - opportunities and challenges for higher education (pp. 1-34). Retrieved from http:// wiki.cetis.ac.uk/images/0/0b/OER_Briefing_Paper.pdf 


\section{Appendix}

\section{Data collection instrument}

Challenges and Instructors' Intention to Adopt and Use Open Educational Resources in Higher Education in Tanzania

Dear Colleague, greetings. My name is J oel S. Mtebe from the Department of Computer Science and Engineering, UDSM. I am conducting a small study to find out reason behind slow adoption of Open Educational Resources (OER) in teaching in Higher Education Institutions (HEIs) in Tanzania. Despite thousands of freely available educational resources in the public domain, many instructors in HLIs have not been adopting them to improve the quality of existing teaching resources. The study is purely academic work designed to help institutions overcome existing challenges for smooth adoption of OER in teaching and learning. Your willingness to participate is very much appreciated

1. Your responses will be treated in confidence and used for the purposes of this study only.

2. Completion of this questionnaire is completely optional.

3. For further information contact J oel S. Mtebejmtebe@gmail.com +255715 383366

Note. For the purpose of this study, OER is defined as free course materials on the internet that are openly to use and adapt for teaching and learning

1. Full name (option)

2. School/ College

3. Have you ever shared your course notes with other lecturers?
a) Yes
b) No

4. Can you share your course notes via internet for people to access freely? why?
a) Yes
b) No

5. Have you ever heard about OER before?
a) Yes
b) No 


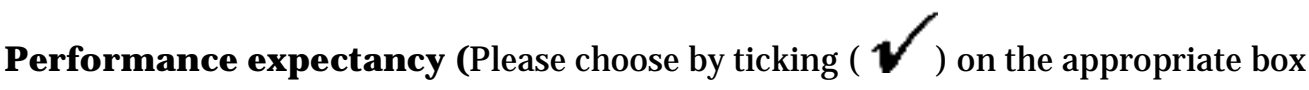

\begin{tabular}{|l|l|l|l|l|l|}
\hline & $\begin{array}{c}\text { Strongly } \\
\text { Disagree }\end{array}$ & Disagree & Neutral & Agree & $\begin{array}{c}\text { Strongly } \\
\text { Agree }\end{array}$ \\
\hline $\begin{array}{l}\text { 6. I would find OER useful in my } \\
\text { courses }\end{array}$ & & & & & \\
\hline $\begin{array}{l}\text { 7. Using OER will enable me to } \\
\text { accomplish course development } \\
\text { activities more quickly }\end{array}$ & & & & & \\
\hline $\begin{array}{l}\text { 8. Using OER will increase learning } \\
\text { outcome of my students }\end{array}$ & & & & & \\
\hline $\begin{array}{l}\text { 9. The use of OER will allow me to } \\
\text { have access to more information } \\
\text { about my courses I teach. }\end{array}$ & & & & & \\
\hline
\end{tabular}

Effort expectancy (Please choose by ticking ( $\sqrt{ }$ ) on the appropriate box

\begin{tabular}{|l|l|l|l|l|l|}
\hline & $\begin{array}{c}\text { Strongly } \\
\text { Disagree }\end{array}$ & Disagree & Neutral & Agree & $\begin{array}{c}\text { Strongly } \\
\text { Agree }\end{array}$ \\
\hline $\begin{array}{l}\text { 10. My interaction with OER } \\
\text { websites will be clear and } \\
\text { understandable. }\end{array}$ & & & & & \\
\hline $\begin{array}{l}\text { 11. It would be easy for me to } \\
\text { become skillful at using and } \\
\text { integrating OER into my courses }\end{array}$ & & & & & \\
\hline 12. I would find OER easy to use. & & & & & \\
\hline $\begin{array}{l}\text { 13. Learning to use OER websites } \\
\text { will be easy for me. }\end{array}$ & & & & & \\
\hline
\end{tabular}

Social influence (Please choose by ticking ( $\sqrt{ }$ ) on the appropriate box

\begin{tabular}{|c|c|c|c|c|c|}
\hline & $\begin{array}{l}\text { Strongly } \\
\text { Disagree }\end{array}$ & Disagree & Neutral & Agree & $\begin{array}{l}\text { Strongly } \\
\text { Agree }\end{array}$ \\
\hline $\begin{array}{l}\text { 14. People who influence my } \\
\text { behavior will think that I should use } \\
\text { and integrate OER into my courses }\end{array}$ & & & & & \\
\hline $\begin{array}{l}\text { 15. People who are important to me } \\
\text { will think that I should use and } \\
\text { integrate OER into my courses }\end{array}$ & & & & & \\
\hline $\begin{array}{l}\text { 16. The lecturers and other staff at } \\
\text { my University will be helpful in the } \\
\text { use and integrate OER into my } \\
\text { courses }\end{array}$ & & & & & \\
\hline $\begin{array}{l}\text { 17. In general, my University will } \\
\text { support the use of OER in teaching } \\
\text { and learning. }\end{array}$ & & & & & \\
\hline
\end{tabular}


Facilitating conditions (Please choose by ticking $(\sqrt{ }$ ) on the appropriate box

\begin{tabular}{|l|l|l|l|l|l|}
\hline & $\begin{array}{c}\text { Strongly } \\
\text { Disagree }\end{array}$ & Disagree & Neutral & Agree & $\begin{array}{c}\text { Strongly } \\
\text { Agree }\end{array}$ \\
\hline $\begin{array}{l}\text { 18. I have the resources necessary to } \\
\text { access OER }\end{array}$ & & & & & \\
\hline $\begin{array}{l}\text { 19. I have the knowledge necessary } \\
\text { to use and integrate OER into my } \\
\text { courses }\end{array}$ & & & & & \\
\hline $\begin{array}{l}\text { 20. OER is similar to other course } \\
\text { content I use for teaching }\end{array}$ & & & & & \\
\hline $\begin{array}{l}\text { 21. A help will be available when I } \\
\text { get problem in using and integrating } \\
\text { OER into my courses }\end{array}$ & & & & & \\
\hline
\end{tabular}

Behavioral intention to use OER (Please choose by ticking ( $\sqrt{ }$ ) on the appropriate box

\begin{tabular}{|l|l|l|l|l|l|}
\hline & $\begin{array}{c}\text { Strongly } \\
\text { Disagree }\end{array}$ & Disagree & Neutral & Agree & $\begin{array}{c}\text { Strongly } \\
\text { Agree }\end{array}$ \\
\hline $\begin{array}{l}\text { 22. I intend to use and integrate } \\
\text { OER into my courses in the future }\end{array}$ & & & & & \\
\hline $\begin{array}{l}\text { 23. I predict I would use and } \\
\text { integrate OER into my courses in } \\
\text { the future }\end{array}$ & & & & & \\
\hline $\begin{array}{l}\text { 24. I plan to use and integrate OER } \\
\text { into my courses in the future. }\end{array}$ & & & & & \\
\hline
\end{tabular}

25. In your own opinion why instructors in higher education in Tanzania do not use OER?

\section{THANK YOU}

\section{Athabasca University $\mathbf{a}$}

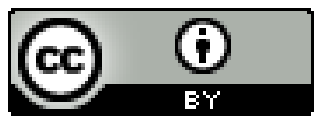

